\section{Udviklingen af det koreanske skriftsprog}

afforskningsbibliotekar, cand.phil. Bent Lerbak Pedersen

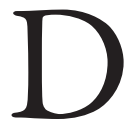
et vides ikke, hvilket skriftsprog koreanerne anvendte, før de adopterede de kinesiske tegn. Kineserne oprettede militære kolonier i det nordlige Korea i 108 f.v.t., og man formoder, at det var herfra, koreanerne blev inspirerede til at benytte de kinesiske tegn. Det første vidnesbyrd om koreanernes brug af dem er en steninskription for den koreanske konge Kwanggaeto (375-413) dateret til år 414 e.v.t.

Datidens koreanere kunne enten vælge at skrive rent kinesisk uden hentydning til eget sprog, eller de kunne skrive koreansk med kinesiske tegn. De skriftkyndige koreanere valgte allerede tidligt, formodentlig i det 4 . århundrede, at benytte den kinesiske lærdom som udgangspunkt for politisk og kulturel udvikling i Korea. På den kinesiske klassiske baggrund formede den koreanske magtelite en skriftkultur, hvor kinesisk skrift var en vigtig del. Til de daglige gøremål i administrationen anvendte de koreansk med kinesiske tegn. Dette var ganske besværligt, da kinesisk og koreansk er to vidt forskellige sprog. Kinesisk er et såkaldt monosyllabisk sprog, hvor hvert tegn har en betydning og en udtale.

Koreansk er et polysyllabisk og agglutinerende sprog, dvs. et sprog udtrykt gennem grammatiske endelser. Koreanske grammatiske endelser er vanskelige at repræsentere med kinesiske tegn, da de grammatiske endelser skal angives uden et meningsbærende element. Derfor måtte koreanerne opfinde en metode til at skrive et forståligt koreansk med kinesiske tegn.

De første skridt mod en udvikling af et skriftligt koreansk med kinesiske tegn skete efter to principper, hvor det ene byggede på mundtlige former og det andet på lokale ord:

1. Fonetisk metode: Et kinesisk tegn blev benyttet til at repræsentere en stavelse uden forbindelse til det kinesiske tegns mening. F.eks. blev det kinesiske tegn for gammel, $g u$, anvendt til at skrive den koreanske stavelse $g u$. I Kina anvender man den samme metode, når man vil angive et fremmed navn, f.eks. bliver Goethe til Gede.

2. Semantisk metode: Til et koreansk ord fandt man et kinesisk tegn med samme betydning. F.eks. udtales vand på koreansk som mul, mens det på kinesisk udtales shui. Man anvendte således det kinesiske tegn shui for det koreanske ord $m u l$.

Fra det 6. århundrede udvikledes gradvist et koreansk skriftsystem, hvor koreansk blev skrevet med kinesiske tegn, men efter koreansk ordfølge.

Det blev systematiseret i slutningen af det 7. århundrede af Solch'ong, der var i tjeneste under kongen Sinmun i Det Forenede Silla (668-935) og kendes under navnet: ido eller imun. Ido blev det administrative skriftsprog i Korea og blev anvendt helt op til den tidlige del af det 20. århundrede. Det kaldes også for sekretærsproget og egnede sig mest til rapporter og dokumenter. Til visse helt specielle koreanske stednavne opfandt man egne kinesiske tegn, og af dem findes 
der op mod 150, men de bliver uhyre sjældent anvendt.

I idosystemet blev en gruppe kinesiske tegn valgt ud til at stå for de koreanske grammatiske stavelser uden hensyn til den oprindelige betydning af tegnet på kinesisk. Som udgangspunkt blev det kinesiske tegn, $z h i$, valgt til at indikere verbernes endelser. Alle de grammatiske endelser blev sat sammen med de meningsbærende tegn, således at en sætning bestod af betydningsbærende tegn og af tegn, der angav de grammatiske endelser. Dette gjorde det meget vanskeligt at læse en sætning, da man skulle vide, hvilke tegn der angav de koreanske ords betydning, og hvilke tegn der tilkendegav de grammatiske former. Tegnene, der henviste til de grammatiske former, havde stadigvæk deres egen betydning, så læseren skulle være i stand til at adskille disse tegn fra dem, der bar betydningsindholdet.

Som en form for hjælp til at adskille de meningsbærende tegn fra de grammatiske tegn, blev udtalen af tegnene valgt til at angive en deling mellem tegnenes funktion. De meningsbærende tegn skulle udtales på rent koreansk, mens de tegn, der var anvendt til de grammatiske endelser, skulle udtales på sino-koreansk, hvor udtalen havde sit udgangspunkt i kinesisk. Dette system blev taget $i$ anvendelse i det 9.-10. århundrede og kaldes hangch'al og opfattes af nogle sprogfolk som et selvstændigt system. En del digtning på rent koreansk er skrevet i dette system, men hangch'al ses meget sjældent anvendt efter det 10. århundrede.

Efterhånden steg antallet af tegn, der skulle angive de grammatiske endelser, og det blev nødvendigt at finde en form for hjæxlpesystem for at lette forståelsen af teksterne. I det 13. og 14. århundrede kom en del af de grammatikbærende tegn til at optræde i forenklede former, således at de var nemmere at se $i$ en sætning. De kinesiske tegn er opbygget af delelementer, og forenklingen gik ud på, at kun enkelte elementer fra det oprindelige tegn blev benyttet. Det kunne man let gøre, da de ikke skulle angive et ords betydning, men en grammatisk form. Forenklingen kunne se ud som følgende:

$$
\text { 厓 } \rightarrow \text { 丁; 伊 } \rightarrow 1 \text {; 尼 } \rightarrow \text { 七; 羅 } \rightarrow \text { 三 }
$$

Systemet kaldes kygyol og synes først at have været udviklet som et hjælpesystem for koreanerne til at læse klassisk kinesisk, f.eks. de konfucianske klassikere, på deres eget sprog. Disse forkortede grammatiske tegn gjorde læsningen lettere og fremmede derved kendskabet til de kinesiske tekster i Korea.

Idosystemet indebar en ganske kompliceret skriftform, der ikke var i stand til at gengive koreansk på den bedste måde. Det koreanske sprogs mange endelser gjorde det næsten umuligt at finde en metode, der kunne anvendes ubesværet. Samtidig var der en tendens til, at ido udviklede sig til et kunstigt skriftsprog uden megen lighed med det talte sprog. Det blev derfor aldrig et rigtigt alternativ til det klassiske kinesiske sprog, der undervistes $i$ inden for de højere sociale lag $\mathrm{i}$ det koreanske samfund, hvor det lykkedes overklassen at fastholde monopolet på skriftsproget og dermed magten helt op til det tidlige 20. århundrede.

\section{Det koreanske alfabet}

I det tidlige 15. århundrede opstod der et ønske hos den daværende konge, Sejong (reg. 1418-1450), om at opfinde et koreansk skriftsprog, der passede til koreansk og ville være let at lære. Sammen med 
en lille gruppe lærde udviklede han et alfabet, der var enkelt i opbygning og let at beherske. I 1446 udgav kongen bogen med det nye alfabet under titlen Hunmin chong'um (Instruktioner til folket om de korrekte lyde). Her blev det nye skriftsystem præsenteret efter en introduktion, hvor kongen begrundede det nye systems fremkomst ud fra sin misfornøjelse med de kinesiske tegns anvendelse i det koreanske sprog. Et alfabet blev opfundet, da det passede bedre til koreansk end tegnskrift. Som der står i forordet: "Vort lands sprog er forskelligt fra det kinesiske og egner sig ikke godt til tegn. Derfor, specielt blandt det almindelige folk, er der mange, der ikke kan udtrykke og udvikle deres ideer. Jeg føler med disse mennesker og har for nylig skabt 28 bogstaver."

I dag kendes det koreanske alfabet under navnet hangul - en betegnelse nationalisten Chu Si-Kyong opfandt i 1910. Ordet han har en dobbelt betydning: Korea eller stor, mens ordet gul betyder skrift. Hangul vil så danne betydningerne: koreansk skrift eller storskrift. Før 1910 kendtes alfabetet almindeligvis under tre forskellige navne: chong'um (korrekte lyde), kugmun (national skrift) eller onmun (vulgær skrift). I Nordkorea kaldes alfabetet i dag enten choson'gul eller uri kulcha (vores skrift).
Choson var navnet på det sidste kongelige dynasti i Korea og indgår i navnet på den nordkoreanske folkerepublik.

Samtidig med Hunmin chong'um blev et skrift med forklarende tekster til det nye alfabet udgivet af den gruppe lærde, der havde bistået kongen i udviklingen af alfabetet: Humin chong'um haerye. Dette skrift forklarer de bagvedliggende grunde til udviklingen af de enkelte bogstaver.

I mange år har lingvister diskuteret heftigt, hvilke former for inspiration der lå til grund for opfindelsen af det koreanske alfabet. Men i 1940 fandt man det forklarende skrift, som ellers mentes at vare gået tabt i tidens løb. Dette afklarede entydigt, hvordan bogstaverne var opbygget.

Mange sprogfolk, især fra den vestlige verden, havde vanskeligt ved at acceptere, at kong Sejong skulle vare opfinderen af det koreanske alfabet, men nyere forskning viser, at det meget vel kan have været kongen selv, eller at han i hvert fald var den drivende kraft bag udviklingen.

Hangul består i dag af 24 grundlæggende bogstaver, men da systemet blev opfundet, var der 28. I tidens lob har sproget været udsat for forandringer, således at fire lyde og dermed fire bogstaver ikke mere anvendes.

Fig. 1: Udgangspunkterne for dannelsen af basiskonsonanterne.
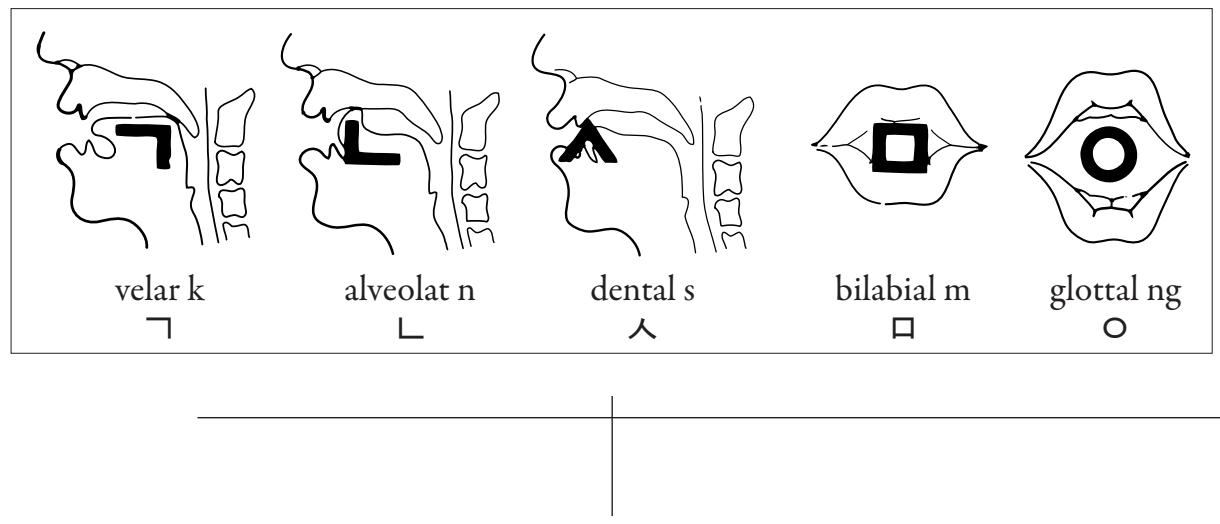
Fig. 2: Udgangspunkterne for dannelsen af basisvokalerne - symboler for:

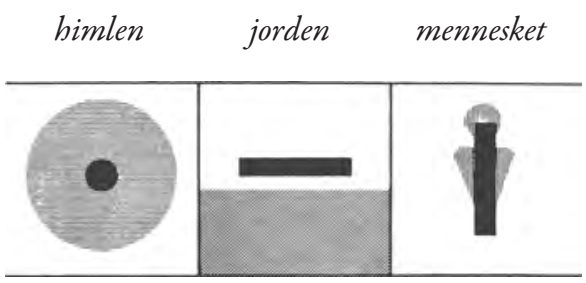

I dag er der således 14 konsonanter og 10 vokaler. Konsonanterne blev formet efter fem positioner af tungen og læberne ved lydfrembringelsen af dem.

Ud fra disse fem basiskonsonanter dannedes de resterende konsonanter ved at tilføje vandrette og lodrette linjer.

Vokalerne blev dannet ud fra metafysiske ideer. Alle ti vokaler er dannet ud fra tre symboler på himlen, der er rund, jorden, der er en horisontal linje, og mennesket, der er en opret linje.

Fem basisvokaler var yderligere dannet ud fra symbolerne for de fire verdenshjørner og centeret samt de fem elementer vand, ild, træ, metal og jord (ler). De fem basisvokaler ser ud som følger:

$$
\perp(\mathrm{o}), \mathrm{T}(\mathrm{u}), \vdash \text { ( } \mathrm{a}), \dashv(\partial) \text { og I (i) }
$$

Ved kombination af de forskellige delelementer fik man de resterende vokallyde, f.eks. $T+\mid=$ 위 (wi).

Ud fra de 24 basiskonsonanter og basisvokaler har man dannet 40 kombinationer, der dækker de lyde, man støder på i koreansk i dag.

Hangul skrives i stavelsesblokke, og ordene skal altid begynde med en konsonant. Der er i princippet intet til hinder for at skrive koreansk bogstav for bogstav ved siden af hinanden, hvilket blev foreslået i det tidlige 20. århundrede, men stavelsesblokkene synes at have en psyko- logisk virkning på den måde, koreanerne læser deres sprog. Det virker, som om stavelsesblokkene fremmer forståelsen af teksterne ved skrivning og læsning. F.eks. skrives Korea med to stavelsesblokke: 한, Han, og 국, kuk, til 한 국, Hanguk. Hvis man i ordet Korea skrev bogstaverne ved siden af hinanden, vil det tage sig ud på denne måde:

$$
\text { 하 ᄂ ᄀ ᄀ }
$$

De ord, der begynder med en vokal, får altid konsonanten $\bigcirc(\mathrm{ng})$ foranstillet, hvorved den i disse tilfælde optræder som en neutral lyd. $\bigcirc$ konsonanten anvendes til lyden $n g$ og placeres da forneden i en stavelse.

Vandrette streger skrives altid fra venstre mod højre, og lodrette streger trakkes altid fra top til bund. F.eks. skrives $p a$ (reb) således 바 og pam (nat) ved at tilføje 밤 (m). So (ko) på denne måde 소 og ved tilføjelse af 손 (n) får man så son (hånd). Sammenskrivningen af stavelserne har ændret sig en smule med tiden, men man kan altid forstå ordene, da placeringen af de enkelte bogstaver ikke ændrer på meningen, men blot kan gøre læsningen en smule langsommere, hvis man ikke er vant til de foreliggende stavelsesblokke.

Der var stærk modstand blandt de lærde mod det nye alfabet, da det blev præsenteret. Kongen svarede, at det ikke var meningen, at hangul skulle overtage de kinesiske tegns rolle i lærdommen, men anvendes til det daglige og blandt større grupper i befolkningen. Men de lærde fastholdt deres kinesiske lærdom og vedblev at skrive koreansk med kinesiske tegn helt op til afslutningen på dynastistyret i Korea i 1910. De lærde betegnede også hangul som et vulgært sprog og et kvindesprog. Dette skyldtes, at hangul 


\begin{tabular}{|c|c|c|}
\hline Hankul & Yale & McCune-Reischauer \\
\hline 7 & $k$ & $k, g$ \\
\hline 77 & $\mathrm{kk}$ & $\mathrm{kk}$ \\
\hline$L$ & $\mathrm{n}$ & $\mathrm{n}$ \\
\hline ㄷ & 1 & 1. d \\
\hline tr. & II & II \\
\hline ᄅ & I & $1, \mathrm{r}$ \\
\hline$\square$ & $m$ & $\mathrm{~m}$ \\
\hline$H$ & $\mathrm{p}$ & $\mathrm{p}, \mathrm{b}$ \\
\hline Hב & Pp & $p p$ \\
\hline$\alpha$ & 5 & $s$ \\
\hline$M$ & ss & ss \\
\hline 0 & ng. & $\mathrm{ng}$ \\
\hline of & a & a \\
\hline 애 & ay & ae \\
\hline 야 & ya & ya \\
\hline 애 & yay & yae \\
\hline 어 & e & $\check{o}$ \\
\hline 에 & ey & e \\
\hline 여 & ye & yo \\
\hline 예 & yey & ye \\
\hline 오 & 0 & 0 \\
\hline 요 & yo & yo \\
\hline 와 & wa & wa \\
\hline 왜 & way & wae \\
\hline 외 & oy & oe \\
\hline 우 & wu & $u$ \\
\hline 워 & we & wช \\
\hline 웨 & wey & we \\
\hline 워 & wi & wi \\
\hline 유 & yu & yu \\
\hline 으 & u & $\tilde{u}$ \\
\hline 의 & uy & ป̀i \\
\hline 이 & $\mathrm{i}$ & $\mathrm{i}$ \\
\hline$x$ & c & ch, j \\
\hline$\pi x$ & cc & tch \\
\hline$\hat{\imath}$ & ch & ch' \\
\hline$\Rightarrow$ & kh & $k^{\prime}$ \\
\hline$E$ & th & $i$ \\
\hline II & ph & $\rho^{\prime}$ \\
\hline$\dot{\gamma}$ & $\mathrm{h}$ & $\mathrm{h}$ \\
\hline
\end{tabular}

var let at lære, så folk fra de lavere sociale klasser og kvinder fra alle samfundslag benyttede sig af hangul. Således var mange af de trykte bøger med hangul af mere populært tilsnit, såsom buddhistiske tekster, historiske krøniker, noveller og romaner, som mange lærde ringeagtede. Da hangul er nemt at lære, havde kong Sejong håbet, at mange koreanere ville tilegne sig det, så den brede befolkning kunne få bedre kundskaber. Men processen kom til at tage lang tid, dels fordi de lærde generelt var imod alfabetet, dels fordi det tog lang tid, før der var tilstrækkelig mange tekster med det nye alfabet til, at virkningen kunne slå igennem.

En del tekster i hangul måtte dog anvende kinesiske tegn for begreber og stednavne, hvor der kun fandtes kinesiske tegn og tilhørende kinesisk udtale, men ikke koreanske ord eller udtale. Derfor findes der mange bøger, hvor man ser en blanding af kinesiske tegn og hangul. Dette fortsatte efter $1910 \mathrm{og}$ findes stadigvæk anvendt i Sydkorea, mens man i Nordkorea har afskaffet de kinesiske tegn $i$ almindelige tekster.

I Sydkorea er der mange hangultekster, hvor forfatterne har valgt at benytte

Til venstre:

Fig. 3: Det koreanske alfabet i dag.

Nedenfor:

Fig. 4: Eksemplerpå markeringen af toner.

\begin{tabular}{|lcllll|}
\hline \multicolumn{7}{c|}{20 thc. } \\
\hline Low & $15 t h c$. & 죽 & cwuk & 'rice gruel' \\
High & 즉 & cywuk & 신 & sin & 'shoes' \\
Rising & 신 & $\bullet \sin$ & 종 & công & 'slave' \\
\hline
\end{tabular}


kinesiske låneord med sino-koreansk udtale, og disse låneord skrives med kinesiske tegn. I visse tekster, der især handler om historiske hændelser, kan man dog ikke undlade en del kinesiske tegn, men hvis man ønsker at skrive med et rent koreansk ordforråd, kan man for det meste anvende hangul alene. Dette er da også ved at blive mere og mere udbredt $\mathrm{i}$ Sydkorea, hvor mange mennesker nu ser hangul som det rigtige skriftsprog. De ser nu de kinesiske tegn som et fremmedelement.

Kong Sejong ønskede også, at det nye alfabet kunne udtrykke koreansk på den mest endegyldige måde, således at alle lyde i sproget kunne gengives korrekt. Samtidig udviklede kongen og hans gruppe af sprogkendere en metode, så sprogets toner også kunne afspejles. På kongens tid var der tre grundlæggende toner: høj, lav og stigende. Disse toner blev angivet med prikker til venstre for stavelseenheden, dvs. ingen prik for lav tone, en prik for høj tone og to prikker for stigende tone. Så kongens ambition om at kunne gengive alle lyde, selv naturens lyde, blev muliggjort, hvilket blev smukt udtrykt i forordet til præsentationen af det nye koreanske skriftsprog i 1446: "'Hangul' er i stand til at skelne mellem ustemt og stemt og kan gengive musik og sang. Det er velegnet til alt praktisk og kan korrekt beskrive lyden af vinden, fuglenes pippen, hanernes galen og hundenes gøen." I dag angives toner ikke i skriften.

Ved gengivelsen af fremmedord vælger man de lydlignende bogstaver til at danne de fremmede ord på koreansk. Dog foretrækker koreanerne at undgå flere konsonanter ved siden af hinanden $i$ et ords begyndelse, således at f.eks. det engelske ord "stop" bliver udtalt "sutop"

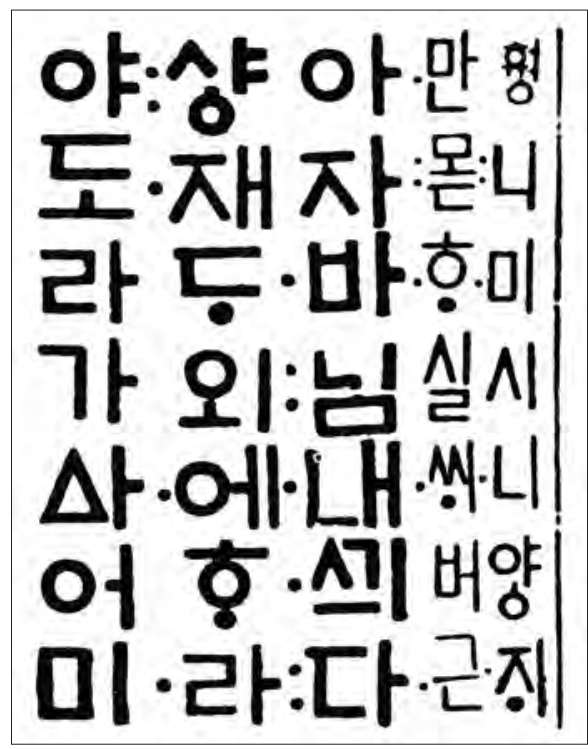

Fig. 5: Eksempel fra det 15. århundredepå hangultryktype. Fra varket Sogposangjol (omskrevet forklaring over Buddhas liv) udgivet i 1449 med lose tratyper.

på koreansk. I Nordkorea har myndighederne forsøgt at erstatte især kinesiske låneord med nye koreanske ord, men også russiske låneord benyttes. Blandt låneord i Sydkorea har engelsk været altdominerende efter 1945. Både i Nord og Syd har myndighederne systematisk fjernet japanske låneord, og man har forsøgt at standardisere ord- og stavelsesformer. Her ses dog, endnu, en mindre forskel mellem de vedtagne retskrivningsformer i Nord og Syd. Kun fremtiden vil vise, om de to koreanske stater nærmer sig hinanden også på sprogområdet.

Den kalligrafiske udvikling af hangulskriften

Siden opfindelsen af det koreanske alfabetet har bogstavernes udseende undergået en forandring. Den oprindelige form be- 


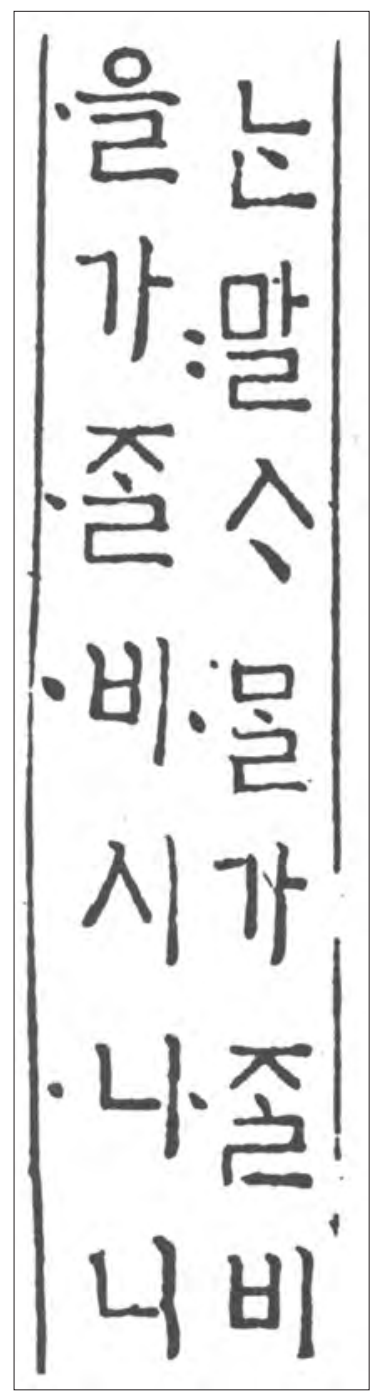

Fig. 6: Eksempel fra det sene 15. arhundrede på hangul-tryktype. Fra verket: Chungdo-ga onhae (Buddhistiske leresetninger) fra 1482 med lose tretyper.

stod af lige tykke linjer uden markeringer af begyndelsen og endelsen på stregerne med fortykkelse, som det ses senere. De

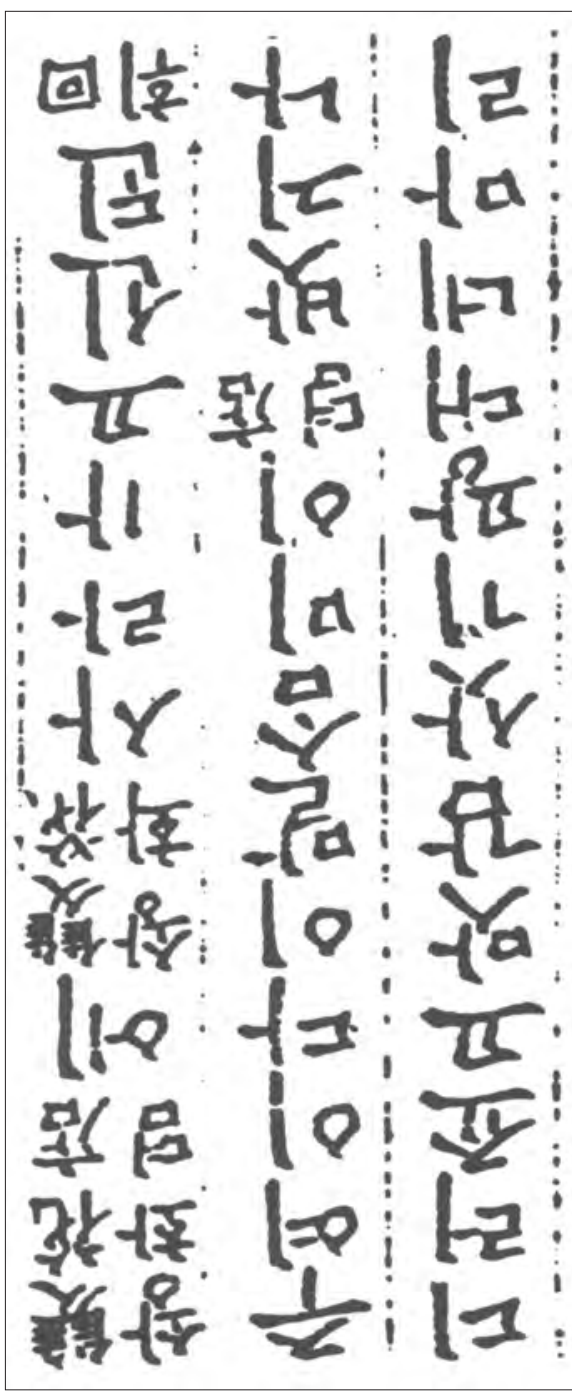

Fig. 7: Eksempel fra det 16. arhundredepa hangul-tryktype. Fra varket: Chuja chungson yossi hyang-yak (digtsamling) fra $1556 i$ trebloktryk.

enkelte bogstavdele var geometrisk placeret i forhold til hinanden, og hver stavelse var sat i et usynligt kvadrat. Angivelsen af 
vokaler blev oprindeligt angivet med en prik, men denne prik blev meget hurtigt erstattet med en vandret streg, da prikken var vanskelig at skrive med en pensel. F.eks. - til $\perp$ og $\mid \bullet$ til $\vdash$. Desuden var det lettere at læse vokalerne med en vandret streg end med en prik. Angivelsen af toner blev dog forsat markeret med en prik op til det 17. århundrede, hvor de forsvandt. Ud over dette ændredes især konsonanterne til mere bløde udgaver af de oprindelige stive og meget retvinklede bogstaver. F.eks. $\neg$ til $\boldsymbol{x}$ og $ᄌ$ til $\boldsymbol{~}$.

Oprindeligt havde kongen og hans støtter forestillet sig, at bogstaverne skulle skrives med penne, men koreanerne var fortrolige med penslen, og den kunne let anvendes til at skrive hangul med.

Fra midten af det 15. århundrede til begyndelsen af det 16 . århundrede udviklede skriften sig væk fra den geometrisk afbalancerede placering inden for et kvadrat. Konsonanten s, 人, fik desuden en lille markering øverst, hvor der tidligere sås en ret vinkel, ^. Begge disse forhold skyldes, at hangul stadig var stærkt påvirket af penselstrøgene i de kinesiske tegn. Lydtegnene blev ligeledes skrevet som en kommaagtig prik og ikke som tidligere, hvor de blev angivet med en cirkel. Disse nye prikker er helt tydeligt frembragt med spidsen af en pensel, der er trykket let ned på papiret.

Indtil det 16. århundrede var der ikke mange lærde, der skrev hangul, de foretrak de kinesiske tegn, men fra 1500-tallet begyndte en del af dem at skrive digte i hangul. Dette påvirkede skrivningen af hangul mod en mere kalligrafisk form. Enhederne i ordene blev mere løseligt forbundet uden at være helt så afhængige af det kvadrat, de tidligere havde været underlagt. Samtidig blev de enkelte streger i bogstaverne varieret således, at de ikke fremstod som lige tykke i geometrisk form. Bøger blev nu både udgivet i en flydende kalligrafisk stil, hvor man bl.a. ser konsonanterne s, $\mathcal{L}$, og ng, a, i asymmetriske former og $i$ en mere regelbundet stil, 人 og O.

I det 17. århundrede forsvandt to lyde fra det koreanske sprog, hvorved de to bogstaver $\Delta$ og $\circ$ forsvandt. I dette århundrede opstod der forskellige former for folkelig litteratur, bl.a. noveller og romaner, og de blev skrevet i hangul. En del af de lærde skrev den folkelige litteratur som en form for fritidsbeskæftigelse og sædvanligvis under pseudonym, da de stadigvæk så ned på denne type litteratur. Blandt hoffets damer blev hangul populært, dels til at skrive breve, digte og beskeder, dels til at læse de nye former for folkelig litteratur. Hofdamerne skrev med pensel, og det bevirkede, at hangulskriften fik et stadig mere individuelt udtryk. I året 1592 blev Korea invaderet af japanerne for første gang, og denne og en senere invasion i 1597 skabte mange dybtgående forandringer i det koreanske samfund også inden for sproget og $\mathrm{i}$ hangul.

Den afsluttende konsonant, $\sqsubset$, forsvandt, og nye stavelsesformer kom til. Hangulskriften i de trykte bøger fik en mere gammeldags form, for man måtte hente $x$ ldre bogstavtyper frem, efter at mange af trykkerierne var blevet ødelagt af de japanske invasionshære.

Først i slutningen af det 19. århundrede ser man endnu en ny udvikling af de koreanske bogstaver. Dette sker med påvirkningen fra den vestlige kultur, hvor koreanerne tager bly i anvendelse til trykning af aviser, tidsskrifter og bøger. Tidligere var de løse metaltyper fremstillet i messing, men bly er nemmere at 
도전으로 간주하고 덤비는 수가 많다. 개룰 무시하지 말고 항상 우호적이 면서도 당당하게 힁동한 것. 그러면 개들의 두려옹온 감소된다. 낮선 개룰 * 빤을 때는 절대 앞질러 뛰어가지 말 것이며 도망치지도 말 것. 퀴거나 도 망치면 개의 추격 본능을 자극에 물리는 경우가 많다. 훅시 게와 마주채 서 개가 좇아을 것처럽 생 각되더라도 천천허 걸어야 한다. 출안하면 개죽으

도전으로 간주하고 덤비는 수가 않다. 개를 무시하지 말고 항상 우호적이 면서도 당당하게 행동할 것. 그러면 개돌의 두려움은 감소된다. 넞선 개 밨율 때는 절대 앞질러 뛰어가지 말 것이며 도망치지도 말 것. 뛰거나 도앙치면 개의 추격 본능울 자극해 물리는 경우가 많다. 축시 개와 마주 체서 개가 ⿳ㅜㅊ아을 것처럼 생각되더라도 천천히 걸어가야 한다. 블안하면

Fig. 8: Eksempler på myöngjo (overst) og gotiske tryktyper.

bearbejde, og det var desuden den form, der blev anvendt i Vesten. Bogstavblokkene blev nu igen mere afbalancerede i kvadrater, og de enkelte streger blev mere lige - dog stadigvæk med fortykkelser som markering af begyndelse og afslutning af stregerne, et kendetegn som kommer fra penselføringen. Udviklingen af bogstavernes udformning gik nærmest i stå i første halvdel af det 20 . århundrede, da japanerne havde annekteret Korea i 1910. Japanerne forsøgte ganske hårdhændet at japanisere koreanerne, og i 1938 blev det forbudt at tale koreansk og dermed også at skrive hangul. Efter japanernes kapitulation i 1945 blev en af de nye skrifttyper, myŏngjo, fra den sidste del af det 19. århundrede ganske populær, og den anvendes stadigvæk i næsten samme form i dag. I denne skriftform er de afsluttende konsonanter i en mindre form, end det ses i de foregående perioder. En anden type, gotisk, nærmede sig den geometriske udformning set $\mathrm{i}$ tidligere tider, dog har den bevaret visse kurvede linjer, som især er tydelige i konsonanterne gog s, ᄀ(M), ᄀ (G); 人(S), 人 (G). Den gotiske stil anses ofte for at være vanskelig at læse, da den bevæger sig væk fra den mere afrundede stil, som ses i myŏngjo og andre nye stiltyper.

Titler og overskrifter er ofte sat med den gotiske type, mens selve teksterne er med myŏngjo eller andre stiltyper. 


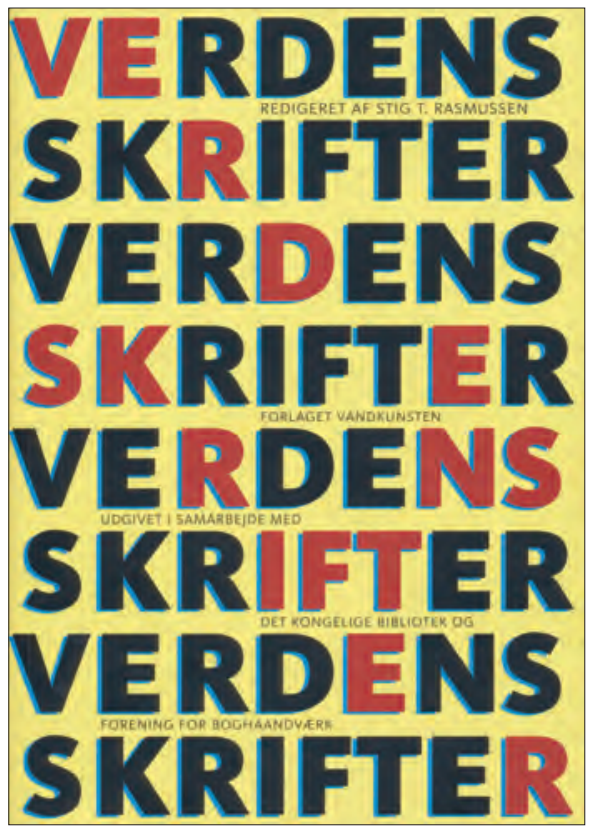

Denne artikel er oprindeligt publiceret i Verdens skrifter. Redigeret af Stig T. Rasmussen. Forlaget Vandkunsten i samarbejde med Det Kongelige Bibliotek og Forening for Boghaandværk. 2011, 392 s. Ill. ISBN 978-87-2695-111-5. Kr. 299,-

Magasin fra Det Kongelige Bibliotek bringer løbende et antal artikler fra Verdens skrifter, skrevet af bibliotekets medarbejdere. 